\title{
Amino Acid Profiles of Ridged Swimming Crab, Charybdis natator Herbst
}

\section{Soundarapandian $\mathbf{P}^{1 *}$, Varadharajan $\mathbf{D}^{1}$, Sivasubramanian $\mathbf{C}^{2}$ and Irin Kumari AS ${ }^{3}$}

${ }^{1}$ Faculty of Marine Sciences, Centre of Advanced Study in Marine Biology, Annamalai University, Parangipettai, Tamil Nadu, India ${ }^{2}$ Department of Zoology, Government Arts College, Dharmapuri, Tamilnadu, India

${ }^{3}$ Department of Zoology, Bharathiar University, Coimbatore, India

\begin{abstract}
Totally 9 essential amino acids were recorded in the present study. Histidine was abundant and Valine was minimum in all sexes. Total essential amino acids were maximum in berried females $(11.396 \mathrm{~g})$ followed by males $(7.529 \mathrm{~g})$ and females $(7.483 \mathrm{~g})$. Totally 11 non-essential amino acids were recorded in the present study. Glutamic acid was uniformly maximum in all sexes. However serine was minimum in all animals irrespective of the sex. Total non-essential amino acids were maximum in berried females $(15.257 \mathrm{~g})$ rather than males $(11.034 \mathrm{~g})$ and females $(8.120 \mathrm{~g})$. From the study it could confirm that amino acids contributed the maximum in berried females followed by males and females. So on the basis of the study it is suggested that to select berried females to eat than males and females.
\end{abstract}

Keywords: Essential; Non-essential; Amino acids; Male; Female; Charybdis natator

\section{Introduction}

The nutritional quality of any animal is determined by their quality and quantity of amino acids [1-3]. In general the fish and shellfish meat is considered to be highly nutritious, owing to its content of essential amino acids and proteins [1-6]. The crab C. natator is consumed by the local population without knowing its nutritional status [3,7]. So the present study is designed to study the amino acid profile of the edible crab C. natator, which is very much useful to popularize this species for aquaculture.

\section{Materials and Methods}

The male, female and berried females of $C$. natator were procured from Parangipettai (Lat. $11^{\circ} 2^{\prime} \mathrm{N}$; Long. $79^{\circ} 46^{\prime} \mathrm{E}$ ) landing centres. The carapace of the crabs was opened and the edible parts of muscle tissues were removed with sharp forceps. The removed muscle tissues were homogenized with pestle and mortar. The grounded muscles were then freeze dried and powdered and eventually stored in refrigerator for further analysis. The amino acids were determined by an automatic amino acid in HPLC analyzer (Lachromehitachi). Five microliter of amino acid standard mixture sample was injected into the column (DENALIC 185 MICROMM $4.6 \mathrm{~mm} \times 150 \mathrm{~mm}$ ). The flow rate was about $1 \mathrm{ml}$ per minute, ambient temperature of $23^{\circ} \mathrm{C}$ was maintained and the sample was detected at $254 \mathrm{~nm}$ by following the method of [8].

\section{Results}

\section{Essential amino acids}

Totally 9 essential amino acids were recorded in the present study (Table 1 and Figure 1). Histidine was abundant and Valine was minimum in all sexes of the present study. Total essential amino acids were maximum in berried females $(11.396 \mathrm{~g})$ followed by males $(7.529 \mathrm{~g})$ and females $(7.483 \mathrm{~g})$. The amount of essential amino acids showed significant difference between different sexes.

\section{Non-essential amino acids}

Totally 11 non-essential amino acids were recorded in the present study (Table 2 and Figure 2). Glutamic acid was uniformly maximum in all sexes. However serine was minimum in all animals irrespective of the sex.
Total non-essential amino acids were maximum in berried females $(15.257 \mathrm{~g})$ rather than males $(11.034 \mathrm{~g})$ and females $(8.120 \mathrm{~g})$. The amino acid contents were significantly varied between different sexes.

\section{Discussion}

Crab is highly nutritious and healthy owing to its essential amino acids, protein content, unsaturated fatty acids and minerals [9-13]. Practically all amino acids can be utilized as chemical signals, although different species using different amino acids as attractants [14]. Among the other compounds amino acids are responsible for the taste of fish flesh, glycine especially is important for the individual taste of different fish species [15]. The crab is usually recommended for pregnant women, for its nutritionally valuable parts of male and female [9].

\begin{tabular}{|c|c|c|c|c|c|}
\hline S.No & Amino acids & Male & Female & Berried female & Total \\
\hline 1 & Histidine & $1.883 \pm 0.13^{\mathrm{b}}$ & $1.453 \pm 0.25^{\mathrm{c}}$ & $2.452 \pm 0.10^{\mathrm{a}}$ & $5.788 \pm 2.13$ \\
\hline 2 & Isoleucine & $1.945 \pm 0.13^{\mathrm{b}}$ & $1.745 \pm 0.20^{\mathrm{c}}$ & $2.045 \pm 0.15^{\mathrm{a}}$ & $5.735 \pm 1.88$ \\
\hline 3 & Leucine & - & $1.000 \pm 0.10^{\mathrm{a}}$ & $0.486 \pm 0.19^{\mathrm{b}}$ & $1.486 \pm 2.12$ \\
\hline 4 & Lysine & $0.306 \pm 0.20^{\mathrm{b}}$ & $0.275 \pm 0.21^{\mathrm{c}}$ & $0.453 \pm 0.1^{\mathrm{a}}$ & $1.034 \pm 0.29$ \\
\hline 5 & Methionine & $1.212 \pm 0.17^{\mathrm{b}}$ & $1.055 \pm 0.19^{\mathrm{c}}$ & $2.433 \pm 0.13^{\mathrm{a}}$ & $4.700 \pm 1.81$ \\
\hline 6 & Phenylalanine & $0.457 \pm 0.18^{\mathrm{b}}$ & $0.345 \pm 0.10^{\mathrm{c}}$ & $0.501 \pm 0.21^{\mathrm{a}}$ & $1.303 \pm 0.01$ \\
\hline 7 & Threonine & $0.506 \pm 0.21^{\mathrm{b}}$ & $0.477 \pm 0.16^{\mathrm{c}}$ & $0.615 \pm 0.15^{\mathrm{a}}$ & $1.598 \pm 1.04$ \\
\hline 8 & Tryptophan & $1.078 \pm 0.19^{\mathrm{b}}$ & $1.008 \pm 0.21^{\mathrm{c}}$ & $2.166 \pm 0.14^{\mathrm{a}}$ & $4.252 \pm 2.14$ \\
\hline 9 & Valine & $0.142 \pm 0.18^{\mathrm{b}}$ & $0.125 \pm 0.17^{\mathrm{c}}$ & $0.245 \pm 0.12^{\mathrm{a}}$ & $0.512 \pm 1.25$ \\
\hline & Total & $7.529 \pm 0.15^{\mathrm{b}}$ & $7.483 \pm 0.10^{\mathrm{c}}$ & $11.396 \pm 1.25^{\mathrm{a}}$ & $25.480 \pm 2.11$ \\
\hline
\end{tabular}

\section{- Absent}

Different superscripts in a rows are significantly different $(P<0.05)$

Table 1: Essential amino acids $(\mathrm{g} / 100 \mathrm{~g})$ in male, female and berried females of C.natator (Values are mean of three values $\pm \mathrm{SE}$ ).

*Corresponding author: Soundarapandian P, Faculty of Marine Sciences, Centre of Advanced Study in Marine Biology, Annamalai University, Parangipettai-608 502 Tamil Nadu, India, Tel: 04144-243223; E-mail: soundsuma@gmail.com

Received August 14, 2014; Accepted October 29, 2014; Published November 10,2014

Citation: Soundarapandian P, Varadharajan D, Sivasubramanian C, Irin Kumari AS (2014) Amino Acid Profiles of Ridged Swimming Crab, Charybdis natato Herbst. J Aquac Res Development 5: 287. doi:10.4172/2155-9546.1000287

Copyright: $\odot 2014$ Soundarapandian P, et al. This is an open-access article distributed under the terms of the Creative Commons Attribution License, which permits unrestricted use, distribution, and reproduction in any medium, provided the original author and source are credited. 


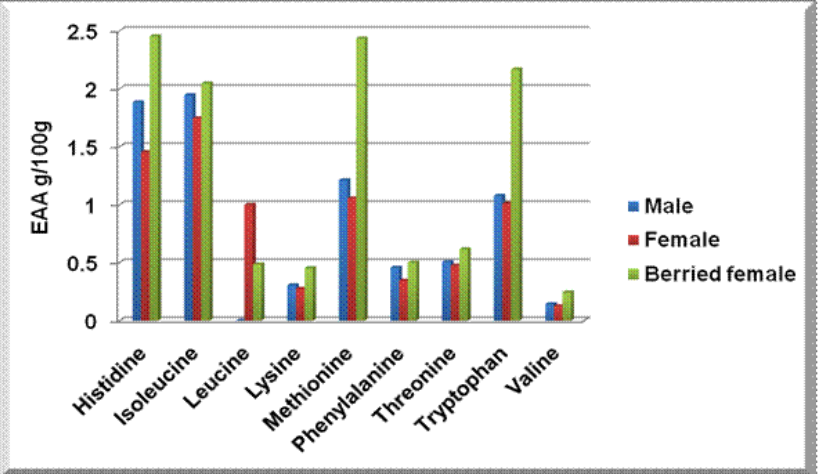

Figure 1: Essential amino acids $(\mathrm{g} / 100 \mathrm{~g})$ in male, female and berried females of $C$. natator

\begin{tabular}{|c|c|c|c|c|c|}
\hline S.No & Amino acids & Male & Female & Berried female & Total \\
\hline 1 & Alanine & $0.144 \pm 0.10^{\mathrm{b}}$ & $0.047 \pm 0.13^{\mathrm{c}}$ & $0.245 \pm 0.10^{\mathrm{a}}$ & $0.435 \pm 1.38$ \\
\hline 2 & Arginine & $0.903 \pm 0.43^{\mathrm{b}}$ & $0.804 \pm 0.22^{\mathrm{c}}$ & $1.452 \pm 0.20^{\mathrm{a}}$ & $3.159 \pm 2.31$ \\
\hline 3 & Aspartic acid & $1.983 \pm 0.25^{\mathrm{b}}$ & $1.752 \pm 0.15^{\mathrm{c}}$ & $2.145 \pm 0.17^{\mathrm{a}}$ & $5.880 \pm 1.32$ \\
\hline 4 & Aspargine & $0.144 \pm 0.21^{\mathrm{b}}$ & $0.104 \pm 0.29^{\mathrm{c}}$ & $0.245 \pm 0.18^{\mathrm{a}}$ & $0.493 \pm 1.08$ \\
\hline 5 & Cystine & $1.981 \pm 0.25^{\mathrm{b}}$ & $0.846 \pm 0.12^{\mathrm{c}}$ & $2.452 \pm 0.15^{\mathrm{a}}$ & $5.279 \pm 1.00$ \\
\hline 6 & Glutamic acid & $3.010 \pm 0.18^{\mathrm{b}}$ & $2.000 \pm 0.17^{\mathrm{c}}$ & $4.230 \pm 0.29^{\mathrm{a}}$ & $9.240 \pm 2.18$ \\
\hline 7 & Glutamine & $0.366 \pm 0.15^{\mathrm{b}}$ & $0.246 \pm 0.10^{\mathrm{c}}$ & $0.452 \pm 0.11^{\mathrm{a}}$ & $1.064 \pm 1.21$ \\
\hline 8 & Glycine & $0.454 \pm 0.19^{\mathrm{b}}$ & $0.385 \pm 0.25^{\mathrm{c}}$ & $0.574 \pm 0.14^{\mathrm{a}}$ & $1.413 \pm 3.21$ \\
\hline 9 & Proline & $1.055 \pm 0.27^{\mathrm{b}}$ & $1.005 \pm 0.19^{\mathrm{c}}$ & $2.086 \pm 0.18^{\mathrm{a}}$ & $4.196 \pm 3.21$ \\
\hline 10 & Serine & $0.099 \pm 0.12^{\mathrm{b}}$ & $0.086 \pm 0.15^{\mathrm{c}}$ & $0.142 \pm 0.18^{\mathrm{a}}$ & $0.327 \pm 1.00$ \\
\hline 11 & Tyrosine & $0.981 \pm 0.29^{\mathrm{b}}$ & $0.845 \pm 0.12^{\mathrm{c}}$ & $1.234 \pm 0.17^{\mathrm{a}}$ & $3.060 \pm 0.38$ \\
\hline & Total & $11.034 \pm 0.18^{\mathrm{b}}$ & $8.120 \pm 0.10^{\mathrm{c}}$ & $15.257 \pm 1.243^{\mathrm{a}}$ & $34.411 \pm 2.34$ \\
\hline
\end{tabular}

Different superscripts in a rows are significantly different $(P<0.05)$

Table 2: Non essential amino acids $(\mathrm{g} / 100 \mathrm{~g})$ in male, female and berried females of $C$. natator (Values are mean of three values $\pm \mathrm{SE}$ ).

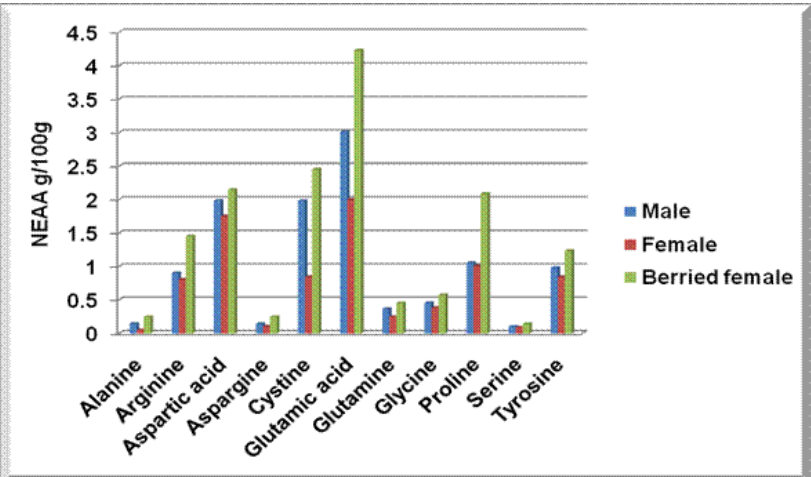

Figure 2: Non essential amino acids $(\mathrm{g} / 100 \mathrm{~g})$ in male, female and berried females of C.natator.

High levels of amino acids control many diseases, such as Crohn's and inflammatory diseases.

The most abundant essential amino acids in all sexes of the present study are histidine, isoleucine, methionine and typtophan. These amino acids constituted $50 \%$ of the total essential amino acids. Glutamic acid, alanine, arginine, glycine, betaine, and adenosine monophosphate might be responsible for the taste of mud crab S. serrata [16]. Almost similar amino acids are also reported in all sexes of $C$. natator of the present study in reasonable quantity. The amino acids histidine and arginine are particularly essential for children [17] and the present investigation also C. natator tissues had rich source of these amino acids.

The total essential amino acids in the berried females, males and females of C. natator are $11.396 \mathrm{~g}, 7.529 \mathrm{~g}$ and $7.483 \mathrm{~g}$ respectively. However total non-essential amino acids in the berried females, males and females are $15.277 \mathrm{~g}, 11.034 \mathrm{~g}$ and $8.120 \mathrm{~g}$ respectively. VilasoaMartinez et al. [18] reported than the total amino acids $20.9 \mathrm{mg} / \mathrm{g}$ in Chinese mitten crab (E. sinensis). Kucukgulmez et al. [19] assessed 7.24 to $7.83 \mathrm{~g} / 100 \mathrm{~g}$ of essential and 9.276 to $8.713 \mathrm{~g} / 100 \mathrm{~g}$ of nonessential amino acids in the blue crab (C. sapidus). Yalcin Kaya et al. [20] recorded $7.458 \%$ of total essential amino acids and $11.381 \%$ of nonessential amino acids in warty crab (Eriphia verrucosa). Manivannan et al. [21] reported that the total essential and nonessential amino acids were $55.537 \%$ and $42.640 \%$ when Acetes sp. fed crabs whereas it was $54.546 \%$ and $40.169 \%$ in clam meat fed crabs of $S$. tranquebarica. The limiting amino acids are often differing among different species. For example, sulphur containing amino acids (methionine and cystine) were reported as the limiting amino acids in Chinese mitten crab meat [22]. However, tryptophan appears to be the limiting amino acid in the meat of both the blue swimming crab and the green crab [23]. Methionine and histamine were found to be the first and second limiting amino acids in shrimps [24]. Histidine was limiting amino acid in P. sanguinolentus [25] and S. tranquebarica [26]. In the present study serine, valine, and alanine are limiting amino acids.

The muscle is apparently the main protein-storage location in crustaceans. In decapods, free amino acids in the tissues reach levels ten times higher than those observed in vertebrates. Several studies suggest that these amino acids may participate in osmoregulation, and in the control of cellular volume [27-29]. Besides free glutamic acid and aspartic acid, free aromatic amino acids such as L-phenylalanine and L-tyrosine also play an important role in enhancing savoury or umami taste at their subthreshold concentrations in the presence of salt and free acidic amino acids [30]. Glycine, alanine, serine and threonine tastes are sweet; while arginine, leucine, valine, methionine, phenylalaine, histidine and isoleucine give bitter taste [31]. Amino acids are the micro molecules and building blocks of proteins which are essential organic compounds consisting of amino as well as acidic groups. In general fish proteins had 20 amino acids. Some of these are listed as Essential Amino Acids (EAA) (histidine, isoleucine, leucine, lysine, methionine, phenylalanine, threonine, tryptophan and valine) because they are not synthesized by the body. Cysteine and tyrosine are also considered as essential if adequate quantity is not available in the body. Fish proteins are rich in these EAA. Specificity of a protein molecule is due to the number and sequence of amino acids. EAA are required for maintenance of life, growth, synthesis of vitamins and reproduction. The lowest level of any one of the EAA in a protein source, which limits the utilization of that protein, makes it the "first limiting amino acid".

Essential Amino Acids (EAAS) are widely used for evaluation of protein quality [18]. Naczk et al. [23] reported the green crab (C. maenas) meat was well balanced in its amino acid composition which is comparable with blue swimming crab P. trituberculatus [32] and Chinese mitten crab [18]. There are 9 essential amino acids are reported in the present study. Each amino acid has its own physiological role once it is consumed. Histidine is one of the major contributors in the crab C. natator irrespective of the sex. However, among the different sexes, histidine is maximum in berried females than males and females. Histidine was already reported in E. sinensis [18] and S. tranquebarica [21]. However it was reported in minimum quantity in P. sanguinolentus 
[25] and S. tranquebarica [26]. Histidine is an indispensable amino acid involved in many metabolic functions including the production of histamines, which take part in allergic and inflammatory reactions. It plays very important role in maintaining the osmoregulatory process and is related to energy production or is used in other metabolic pathways during certain emergencies harsh conditions [33]. It is found abundantly in heamoglobin and used in the treatment of rheumatoid arthritis, allergies, ulcers and anaemia. It is essential for the growth and repair of tissues; important for the maintenance of the myelin sheaths, which protect nerve cells. It is needed for the production of both red and white blood cells; protects the body from radiation damage; lowers blood pressure, aids in the removal of heavy metals from the body. Histidine aids in sexual arousal.

Isoleucine is one of the major contributors in the crab C. natator. Isoleucine is maximum in berried females than males and females of $C$. natator. Isoleucine was already reported in P. sanguinolentus [25], E. sinensis [18] and $S$. tranquebarica [21,26]. Isoleucine is needed for the heamoglobin formation, stabilizes and regulates blood sugar and energy levels. It is valuable for athletes because it aids in the healing and repair of muscle tissue, skin and bones. Isoleucine is found to be deficient in people suffering from certain mental and physical disorders. Leucine is maximum in berried females and it was totally absent in males of $C$. natator. Leucine was already reported in various crabs $[18,21,25,26]$ and shrimps [24]. Leucine with Isoleucine and Valine to promote the healing of muscle tissue, skin, and bones. Leucine is recommended for those recovering from surgery, lowers blood sugar levels and aids in increasing growth hormone production. Leucine is a ketoneproducing amino acid. It could be transformed into acetyl-CoA and acetyl-acetic acid, which are important intermediates in carbohydrate and lipid metabolism [34]. Lysine is maximum in berried females than males and females of $C$. natator. Lysine was already reported in various crabs $[18,21,25,26]$ and shrimps [24]. Lysine ensures adequate calcium absorption and maintains a proper nitrogen balance in adults and helps to form collagen (which makes up cartilage and connective tissue). It also aids in the production of antibodies which have the ability to fight cold sores and herpes outbreaks. It also lowers high serum triglyceride levels. Methionine is one of the major contributors in the crab C. natator. Methionine is maximum in berried females that followed by males and females of $C$. natator. In general methionine contribution was moderate in S.tranquebarica [26], E. sinensis [18], shrimps [24] and totally absent in P. sanguinolentus [25]. Methionine is powerful anti-oxidant and a good source of sulfur, which prevents disorders of the hair, skin, and nails; assists the breakdown of fats, thus helping to prevent a buildup of fat in the liver and arteries that might obstruct blood flow to the brain, heart, and kidneys. It helps to detoxify harmful agents such as lead and other heavy metals; helps diminish muscle weakness; prevents brittle hair; protects against the effects of radiation; beneficial for women who take oral contraceptives because it promotes the excretion of estrogen; reduces the level of histamine in the body which can cause the brain to relay wrong messages; helpful to individuals suffering from schizophrenia. Phenylalanine is maximum in berried females than females and males of $C$. natator. Phenylalanine was already reported in various crabs $[18,21,25,26]$ and shrimps [24]. Phenylalanine is used by the brain to produce norepinephrine, a chemical that transmits signals between nerve cells in the brain; promotes alertness and vitality; elevates mood; decreases pain; aids memory and learning; used to treat arthritis, depression, menstrual cramps, migraines, obesity, Parkinson's disease, and schizophrenia. Threonine is maximum in berried females that followed by males and females of $C$. natator. Threonine was already reported in various crabs
$[18,21,25,26]$ and shrimps [24]. Threonine helps to maintain proper protein balance in the body; is important for the formation of collagen, elastin and tooth enamel; aids liver and lipotropic function when combined with aspartic acid and methionine; prevents the buildup of fat in the liver; assists metabolism and assimilation.

Tryptophan is one of the major contributors in the crab C. natator. In individual contribution tryptophan is maximum in berried males than females and males. Tryptophan was already reported in E. sinensis [18] and totally absent in P. sanguinolentus [25], S. tranquebarica [21,26] and shrimps [24]. Tryptophan is a natural relaxant, helps alleviate insomnia by inducing normal sleep; reduces anxiety and depression and stabilizes mood; helps in the treatment of migraine headaches; helps the immune system function properly; aids in weight control by reducing appetite; enhances the release of growth hormones; helps to control hyperactivity in children. The amino acid tryptophan plays an important role in the brain as a precursor of the neurotransmitter, serotonin, which has a major effect on the feeding behavior of animals [35]. Valine contribution is minimum when compared to other amino acids in C. natator. In individual contribution Valine is maximum in berried females than females. Valine was already reported in various crabs [18,21,25,26] and shrimps [24]. Valine is needed for muscle metabolism and coordination, tissue repair, and for the maintenance of proper nitrogen balance in the body; used as an energy source by muscle tissue; helpful in treating liver and gallbladder disease; promotes mental vigor and calm emotions. Valine is involved in many metabolic pathways and is considered indispensable for protein synthesis and optimal growth [36].

Alanine contribution is minimum when compared to other amino acids in C. natator. In individual contribution alanine is maximum in berried females than females and males in C. natator. Alainine was already reported in various crabs [18,21,25,26] and shrimps [24]. Alanine is a non-essential amino acid plays a major role in the transfer of nitrogen from peripheral tissue to the liver; aids in the metabolism of glucose, a simple carbohydrate that the body used for energy; guards against the buildup of toxic substances that are released into muscle cells when muscle protein is broken down quickly to meet energy needs, such as what happens with aerobic exercise; strengthens the immune system by producing antibodies. Arginine is maximum in berried females than males and females of $C$. natator. Arginine contribution was already reported to be maximum in various crabs $[18,21,25,26]$ and shrimps [24]. Arginine is considered "The Natural Viagra" by increasing blood flow to the penis; retards the growth of tumors and cancer by enhancing the immune system; increases the size and activity of the thymus gland, which manufactures $\mathrm{T}$ cells, crucial components of the immune system; aids in liver detoxification by neutralizing ammonia; reduces the effects of chronic alcohol toxicity; used in treating sterility in men by increasing sperm count; aids in weight loss because it facilitates an increase in muscle mass and a reduction of body fat; assists the release of growth hormones, which is crucial for "optimal" muscle growth and tissue repair; is a major component of collagen which is good for arthritis and connective tissue disorders; aids in stimulating the pancreas to release insulin.

Aspartic acid is maximum in berried females than males and females of C. natator. Aspartic acid was already reported in various crabs $[18,21,25,26]$ and shrimps [24]. Aspartic acid increases stamina and is good for chronic fatigue and depression; rejuvenates cellular activity, cell formation and metabolism, which gives you a younger looking appearance; protects the liver by aiding the expulsion of ammonia; combines with other amino acids to form molecules 
that absorb toxins and remove them from the bloodstream; helps to facilitate the movement of certain minerals across the intestinal lining and into the blood and cells; aids the function of RNA and DNA, which are carriers of genetic information. Cystine is maximum in berried females than males and the females of $C$. natator. Cystein was already reported in various crabs $[18,21,25,26]$ and shrimps [24,37]. Cystine is functions as a powerful anti-oxidant in detoxifying harmful toxins; protects the body from radiation damage; protects the liver and brain from damage due to alcohol, drugs, and toxic compounds found in cigarette smoke; has been used to treat rheumatoid arthritis and hardening of the arteries; promotes the recovery from severe burns and surgery; promotes the burning of fat and the building of muscle; slows down the aging process. Skin and hair is made up of $10-14 \%$ cystine.

Glutamic acid contribution is maximum when compared to other amino acids in C. natator. Glutamic acid is maximum in berried females than males and females. Glutamic acid contribution was already reported to be maximum in various crabs $[18,21,25,26]$ and shrimps [24,37]. Glutamic acid is an excitatory neurotransmitter for the central nervous system, the brain and spinal cord; important in the metabolism of sugars and fats; aids in the transportation of potassium into the spinal fluid; acts as fuel for the brain; helps correct personality disorders, and is used in the treatment of epilepsy, mental retardation, muscular dystrophy, and ulcers. Glutamine is maximum in berried females than males and females of C. natator. As per the previous study glutamine is not common amino acid in crabs and shrimps. Glutamine is usually found in muscles; helps build and maintain muscle tissue; helps prevent muscle wasting that can accompany prolonged bed rest or diseases such as cancer and AIDS; a "brain fuel" that increases brain function and mental activity; assists in maintaining the proper acid/alkaline balance in the body; promotes a healthy digestive tract; shortens the healing time of ulcers and alleviates fatigue, depression and impotence; decreases sugar cravings and the desire for alcohol; recently used in the treatment of schizophrenia and senility. Glycine is maximum in berried females than males and females of $C$. natator. Glysine was already familiar amino acids in crabs $[18,21,25,26]$ and shrimps [24]. Glycine is retards muscle degeneration; improves glycogen storage, thus freeing up glucose for energy needs; promotes a healthy prostate, central nervous system, and immune system; useful for repairing damaged tissue and promotes healing.

Proline is maximum in berried females than males and females of C. natator. Proline was already reported in crabs $[18,21,25,26]$ and shrimps [24,37]. Proline improves skin texture by aiding the production of collagen and reducing the loss of collagen through the aging process; helps in the healing of cartilage and the strengthening of joints, tendons, and heart muscle; works with Vitamin C to promote healthy connective tissues. Serine is minimum when compared to other amino acids in C. natator. It is maximum in berried females than males and females of $C$. natator. Serine was already reported in crabs $[18,21,25,26]$ and shrimps [24]. Serine is needed for the proper metabolism of fats and fatty acids, the growth of muscle, and the maintenance of a healthy immune system; is a component of the protective myelin sheaths that cover nerve fibers; is important in RNA \& DNA function and cell formation; aids in the production of immunoglobulins and antibodies. Tyrosine is maximum in berried females than males and females of $C$. natator. Tyrosine was already reported in crabs $[18,21,25,26]$ and shrimps [24]. Tyrosine is important for overall metabolism; is a precursor of adrenaline, nor epinephrine, and dopamine, which regulate mood and stimulates metabolism and the nervous system; acts as a mood elevator, suppresses the appetite, and helps to reduce body fat; aids in the production of melanin (the pigment responsible for hair and skin colour) and in the functions of the adrenal, thyroid, and pituitary glands; has been used to help chronic fatigue, narcolepsy, anxiety, depression, low sex drive, allergies and headaches. Proline showed an important adjustment necessary for osmoregulation, following changes in osmotic stress. From the study it could be confirm that amino acids contributed maximum in berried females followed by males and females. So on the basis of the study it is suggested that to select berried females to eat than males and females.

\section{References}

1. Allen WV (1971) Amino acid and fatty acid composition of the tissues of the Dungeness crab (Cancer magister). J Fish Res Board Can 28: 1191-1195.

2. Mente E, Coutteau P, Houlihan D, Davidson I, Sorgeloos P (2002) Protein turnover, amino acid profile and amino acid flux in juvenile shrimp Litopenaeus vannamei: Effects of dietary protein source. J Exp Biol 205: 3107-3122.

3. Rosa R, Nunes ML (2003) Seasonal changes in nucleic acids, amino acids and protein content in juvenile Norway lobster (Nephrops norvegicus). Mar Biol 143: $565-572$.

4. Silvia G, Abel-Antonio U, Francisco V, Georgina $\mathrm{H}$ (2003) Ammonia efflux rates and free amino acid levels in Litopenaeus vannamei postlarvae during sudden salinity changes. Aquacult 233: 573-581.

5. Wang W, Wang A, Bao L, Wang J, Liu Y, et al. (2004) Changes of protein-bound and free amino acids in the muscle of the freshwater prawn Macrobrachium nipponense in different salinities. Aquacult 233: 561-571.

6. Martinez MV, Hernandez JL, Lage-Yusty MA (2007) Protein and amino acid contents in the crab, Chionoecetes opilio. Food Chem 103: 1330-1336.

7. Soundarapandian P, Singh RK (2008) Biochemical Composition of the Eggs of Commercially Important Crab Portunus pelagicus (Linnaeus). Inter J Zoo Res 4: 53-58.

8. Baker DH, Han Y (1994) Ideal amino acid profile for chicks during the first three weeks post hatching. J Poultry Sci 73: 1441-1447.

9. Adeyeye El (2002) Determination of chemical composition of the nutritionally valuable parts of male female common West African freshwater crab. Sudanautes africanus africanus. Int J Food Sci Nutr 52: 189-196.

10. Gokoglu N, Yerlikaya P (2003) Determination of proximate composition and mineral contents of blue crab (Callinectus sapidus) and swim crab (Portuns pelagicus) caught off the Gulf of the antalya. Food Chem 80: 495-498.

11. Celik K, Tureli C, Celik M, Yanar Y, Erdem U, et al. (2004) Fatty acid composition of the blue crab (Callinectus sapidus Rathbun, 1896) in the north eastern Mediterrean. Food Chem 88: 271-273.

12. Skonberg DI, Perkins BL (2002) Nutrient composition of green crab (Carcinus maenas) leg meat and claw meat. Food Chem 77: 401-404

13. Wu X, Zhou B, Cheng Y, Zeng C, Wang C, et al. (2010) Comparison of gender differences in biochemical composition and nutritional value of various edible parts of the blue swimmer crab. J Food Comp Anal 23: 154-159.

14. Zimmer Faust RK (1998) The relationship between chemoreception and faraging behaviour in crustaceans. Linnol Ocenogr 34:1367-1374

15. Standsby ME (1962) Proximate compostion of fish. In: Heen ME, Kreuzer R (edn). Fish nutrition. fishimng News (Book) Ltd., London. pp 55-60.

16. Prasad PN, Neelakandan B (1989) Proximate and essential amino acid composition in edible crab Scylla serrata. Comp Physiol Ecol 14: 34-37.

17. FAO/WHO/UNU (1985) Expert consultation. Energy and protein requirements. Technical report series 724. World Health Organization, Geneva

18. Vilasoa-Martinez M, Lopez-Hernandez J, Asuncion M, Lage-Yusty MA (2007) Protein and amino acid contents in the crab, Chionoecetes opilio. Food Chem 103: $1330-1336$

19. Kucukgulmez A, Celik M (2008) Amino acid compostion of the blue crab (Callinectus sapidus) from the north Eastern mediterranean. JABS 2: 39-42.

20. Yalcin Kaya, Huiya Turan, Emin Endren M (2009) Determination of nutritional quality of warty crab (Eriphyis verrucosa Forskal, 1775). J Ani Vet Adv 8: 120 124.

21. Manivannan K, Sudhakar M, Murugesan R, Soundrapandian P (2010) Effect 
Citation: Soundarapandian P, Varadharajan D, Sivasubramanian C, Irin Kumari AS (2014) Amino Acid Profiles of Ridged Swimming Crab, Charybdis natator Herbst. J Aquac Res Development 5: 287. doi:10.4172/2155-9546.1000287

Page 5 of 5

of feed on the Biochemical composition of commercially important mud crab Scylla tranquebarica (Fabricius, 1798). Int J Anim Vert Adv 2: 16-20.

22. Chen HP, Zhang M, Shrestha S (2007) Compositional characteristics amd nutritional quality of Chinese mitten crab (Eriocheir sinensis ). Food Chem 103: 1343-1349.

23. Naczk M, Williams J, Brennam K, Liyanaspathiramma, Shahidi F (2007) Compositional characteristics of green crab (Carcinus sapidus). Food Chem 88: $429-434$

24. Yannar Y, Celik M (2006) Seasonal amino acid profiles and mineral contents of green tiger shrimp (Penaeus seminsulcatus De Haan, 1844) and speckled shrimp (Metapenaeus monoceros, Fabricius, 1789) from the eastern Mediterrranean. Food Chem 94: 33-36.

25. Sudhakar M, Manivannan K, Soundarapandian P (2009) Nutritive value of hard and soft shell crabs of Portunus sanguinolentus (Herbst). Internat $\mathrm{J}$ Ani Vet Adv 1: 44-48.

26. Thirunavukkarasu N (2005) Biology, nutritional evaluation and utilization of mud crab Scylla tranquebarica (Fabricius, 1798). Ph.D. Thesis, Annamala University, India 126.

27. Gilles R (1982) Osmoregulatory process in molluscs and crustacean form media with fluctuating salinity regime. Biol Fisiol Anim 6: 1-36.

28. Chang E, Oconnor JD (1983) Metabolism and transport of carbohydrates and lipids. In: Mantel LH (edn). The biology of Crustacea. Inter Anat Physiol Regul Acad Press, New York 5: 263-287.

29. Schein V, Wache Y, Etgens R, Kucharski KL, Wormhoudt AV, et al. (2004)
Effect of hyperosmotic shock on phosphoenolpyruvate carboxykinase gene expression and glucogenic activity in the crab muscle. FEBS Lett 561: 202-206.

30. Lioe, HN, Apryantono A, Takara K, Wada K, Naoki H, et al. (2004) Low molecular weight compounds responsible for savory taste of Indonesian soy sauce. J Agric Food Chem 52: 5950-5956.

31. Sikorski ZE, Lolakowska A, Pan BS (1990) The nutrition compostion of the major groups of marine food oraganisms. In: Sikorski ZE (edn). Res Nut comp Preser. Boca Raton, Florida: CRC Press-Inc. 30-52.

32. Su XR, Li TW, Oyang F, Li P (1996) Study on the nutritive composition of Portunus trituberculatus. Acta Nutrimenta Sinica 18: 342-346.

33. Abe H, Ohmama S (1987) Effect of starvation and sea water acclimation on the concentration of free L-histidine and relateds dipetides in the muscle of eel, rainbow trout and Japanese dace. Com Biochem Physiol 88: 507-511.

34. Shen T, Wang JY (1990) Biochemistry [M], Higher Education Publisher, 67-86.

35. Mullen BJ, Martin RJ (1992) The effect of dietary fat on diet selection may involve entral serotonin. Am J Physiol 263: 559-563.

36. Wilson JA (2002) Scientific Uncertainty, Complex Systems, and the Design of Common-pool Institutions.' In The Drama of the Commons National Research Council, Committee on the Human Dimensions of Global Change, National Academy Press. 327-359.

37. Takada K, Aoki T, Kunisaki N (1998) Proximate composition, free amino acid fatty acid, mineral and cholesterol contents in imported frozen shrimps. Nippon Suisan Gakkaishi Bull Jap Soc Sci Fish 54: 2173-2179. 